\title{
A multiple harvest cultivation strategy for ethanol production from sweet sorghum throughout the year in tropical ecosystems
}

\author{
Carlos Rolz ${ }^{\mathrm{a} *}$, Robert de León ${ }^{\mathrm{a}}$, Ana Luisa Mendizábal de Montenegro ${ }^{\mathrm{a}}$, Vilma Porras ${ }^{\mathrm{b}}$, Rolando \\ Cifuentes ${ }^{\mathrm{b}}$ \\ ${ }^{a}$ Biochemical Engineering Center, Research Institute, Universidad del Valle de Guatemala, \\ Guatemala ${ }^{\mathrm{b}}$ Agriculture and Food Studies Center, Research Institute, Universidad del Valle de \\ Guatemala, Guatemala \\ *e-mail: carlosrolz@uvg.edu.gt
}

\begin{abstract}
Sweet sorghum is a sugar rich crop that has been considered an alternative feedstock to sugarcane for ethanol production. A full year production cycle is possible as sweet sorghum is capable of multiple harvests. In this work we present experimental results for stalk biomass and sugar productivities, individual sugar distribution at harvest, ethanol yield and productivity of several sweet sorghum varieties and three harvests, the first cut during the rainy period and two ratoon crops during the dry season. The fresh stalk biomass productivity was different among varieties and harvests. All varieties had a lower than expected first harvest productivity, short waterlogging periods during the rainy period might have been the cause, and Top 76-6 showed the best value, $118 \mathrm{Mg}$ per ha. The stalk sugar content dropped drastically for the second ratoon crop which also had an atypical sugar distribution, sucrose content decreased and reducing sugars increased, a premature harvest might have been the possible cause. Umbrella and Top 766 had the highest sugar productivity around $10 \mathrm{Mg}$ per ha year. Fructose was the only remaining sugar after fermentation. Top 76-6 showed the highest ethanol productivity of around 4,800 liters per ha year and the best overall process efficiency.
\end{abstract}

\section{Key Words}

Sweet sorghum; multiple harvests; stalk productivity; sugar productivity; ethanol productivity 


\section{Introduction}

Sweet sorghum is a sugar rich crop that has been considered an alternative feedstock to sugarcane for first generation ethanol production in tropical countries, due to its efficient C4photosynthesis, short production cycle, nitrogen and water use efficiency, high tolerance to environmental stress and adaptability to marginal lands [1-5]. Two alternative scenarios have been considered previously for sweet sorghum planting in the tropics.

The first alternative contemplates a sweet sorghum harvest management in order to fill the idle time in the year that ethanol plants processing sugarcane byproducts have [6,7]. For example, in Central America sugarcane is harvested from middle November to late April, the period in which sugar factories supply molasses to ethanol distilleries. However, ethanol distilleries could operate all year if sweet sorghum harvests could be programmed from May to October supplying sweet sorghum juice for fermentation.

The second alternative centers on a full year production cycle as sweet sorghum in the tropics is capable of two ratoon crops as we showed recently [8]. Ratooning is a harvesting technique that leaves uncut the lower parts of the plant, from which the ratoon crop develops. Employing such method the costs associated with soil preparation and seed planting decrease. For many tropical countries this alternative could foster the much needed economic development of marginal land away from sugarcane plantations. It must be noted that sweet sorghum presents an additional advantage over sugarcane as a biofuel feedstock due to its multiproduct crop characteristic, that is, a high sugar productivity and grain production with adequate nutritional characteristics [9].

However in order to achieve an optimum full year production cycle questions regarding the proper time to sow remain. In our previous publication [8] the sweet sorghum varieties, Della, M81-E, Sugar Drip, Top 76-6, and Umbrella, planted in our South Campus located in the Guatemalan Pacific lowlands in 2011 and 2012, sowed in the middle of January and harvested in April during the dry season, with ratoon crops harvested in July and November during the rainy period, showed a significant decrease in stalk biomass productivity for the ratoon crops. Instead of such production scheme, sowing could be done during the rainy season period which runs 
from May to November in order to have ratoon harvests during the dry season expecting with this change to increase the ratoon crops stalk biomass productivity.

In the present work we present experimental results for stalk biomass productivity, stalk sugar content, sugar productivity, and individual sugar distribution at harvest, ethanol yield and ethanol productivity for first cut, first and second ratoon crops of the sweet sorghum varieties, Della, M81-E, Sugar Drip, Top 76-6, and Umbrella, sowed in July during the rainy season with harvests in October, and ratoon crops in February and April during the dry season.

\section{Materials and Methods}

\subsection{Experimental site and sweet sorghum planting}

The experimental plot was located in our South Campus located in the Guatemalan Pacific lowlands at Santa Lucia Cotzumalguapa, Escuintla at 300 meters above sea level. The soil was an Andisol rich in volcanic material, with a $\mathrm{pH}$ of 5.6 and 227,160 and $<9 \mathrm{mg} / \mathrm{kg}$ of total nitrogen, potassium and total phosphorus, respectively. The sweet sorghum varieties tested were Della, M81-E, Sugar Drip, Top 76-6, and Umbrella. The last two varieties had shown before higher stalk biomass and sugar productivities and grain with adequate nutritional characteristics, M81-E had consistently shown high stalk biomass productivity, and the other two varieties were in between $(8,9)$. Sowing was done in early July 2013 and the first harvest took place in late October after 115 days, the plant development period took place entirely during the rainy season as shown in Figure 1. On the other hand, the ratoon crops took place during the dry season; the first ratoon was harvested in early February 2014 after 109 days, and the second ratoon was harvested in late May after 107 days at the start of the rainy period. In all cases harvest time was established by testing manually the grain hardness until the soft dough stage was reached. The monthly average, maximum and minimum temperatures and precipitation are shown in Figure 1. A randomized complete block with three replications was used as the experimental design with plant density the same as the one employed previously at the same site [8,9]. The fertilization employed for the first cut and the two ratoon crops was $100 \mathrm{kgN}$ per ha, applied as follows, one third two weeks after sowing, one third after 1 month, and one third after 2 months. Also, $50 \mathrm{~kg}$ $\mathrm{P}_{2} \mathrm{O}_{5}$ and $50 \mathrm{~kg} \mathrm{~K} \mathrm{~K}_{2} \mathrm{O}$ per ha were incorporated at the first application. No irrigation was done during the first harvest as it took place when the rainy season started. Furrow irrigation was 
implemented three times weekly late in the first ratoon crop and early in the second ratoon crop, when there was lower precipitation as shown in Figure 1.

\subsection{Stalk sampling and handling}

The stalk biomass average productivity was obtained by harvesting the two central rows of four sorghum rows cut manually at ground level for each experimental unit, cleaning and weighing the stalks, removing the top and repeating the procedure for each replication. Each time for every variety a sub-sample was taken consisting of 12 to 15 stalks chosen randomly from the three field replications and were sent on the same day to the laboratory in our central campus. They were stored at $-10{ }^{\circ} \mathrm{C}$ until processed. The twelve to fifteen thawed stalks for each variety and each harvest were processed as follows: the second to four internodes, counting from the bottom, of two stalks chosen randomly were cut employing a small hand saw. The stalk segments were reduced into small pieces with a knife. These were further pulverized employing a laboratory high-speed cutting mill (IKA Works A11). A known amount of solid particles as described below was used for fermentation purposes. Another amount, about $5 \mathrm{~g}$, of the pulverized material was placed in an oven at $65{ }^{\circ} \mathrm{C}$ (Fisher Scientific Isotemp Incubator) until constant weight for moisture determination. The rest of the stems, 10-13 stalks, were pressed employing a stainless steel pilot three roll crushing mill (Vencedora Maqtron Model 721) with a 2-HP motor. Juice Brix was measured with a digital refractometer (Model 300034 Sper Scientific Ltd) and sugar analysis was carried out as described below.

\subsection{Yeast growth, culture media and ethanol production.}

The yeast employed was a commercial Saccharomyces cerevisiae strain used for years by Guatemalan distilleries and adapted to sugar cane molasses. Yeast was grown in a 30-g/L Sabouraud broth (Merck, $2 \%$ glucose, $0.5 \%$ animal peptone, and $0.5 \%$ casein peptone) plus 1 $\%$ additional sucrose. One hundred and twenty-five milliliters of broth was added into a 250-mL flask, sterilized at $121{ }^{\circ} \mathrm{C}$ for $20 \mathrm{~min}$, cooled, inoculated, and agitated at $250 \mathrm{rpm}$ at $30{ }^{\circ} \mathrm{C}$ for 48 h (Incubator Shaker Lab Companion Model SI-600). The suspension was centrifuged at 1,600g, $10^{\circ} \mathrm{C}$ for $5 \mathrm{~min}$ (Eppendorf Table-top Refrigerated Centrifuge Model 5804R). The solid pellet was suspended in deionized water and the optical density adjusted to 1.2 which corresponded to approximately $1.0 \mathrm{~g}$ dry yeast/L. A volume of $100 \mathrm{~mL}$ of the suspension was used to inoculate 
approximately $30 \mathrm{~g}$ of pulverized sweet sorghum placed in a flask. The average amount of yeast employed was $20 \mathrm{~g}$ of dry yeast $/ \mathrm{kg}$ of dried sorghum particles. The flasks were kept at $30{ }^{\circ} \mathrm{C}$ for $36 \mathrm{~h}$. Each sorghum variety was run in duplicate. The solid water proportions inside the flask assured that all particles were submerged in order to facilitate the simultaneous sugar extraction and fermentation. Employing this technique we avoided the cumbersome and incomplete sugar extraction achieved by stalk pressing.

\subsection{Analytical determinations}

Sugars in the pressed sweet sorghum juice and in the filtrate from the flasks at the end of the fermentation were determined with an Agilent 1100 high-pressure liquid chromatograph, an Agilent 1200 refractive index detector, and a Zorbax NH2, $25 \mathrm{~cm}$ long and $4.6 \mathrm{~mm}$ internal diameter column, employing acetonitrile in water (70-30) as the solvent phase. Ethanol was quantified employing an Agilent 6890N gas chromatograph, with an HPPlot/ Q, $30 \mathrm{~m}$ long and $32 \mathrm{~mm}$ internal diameter column.

\subsection{Mathematical analysis}

Two-way analysis of variance was used with the fresh stalk biomass productivity data using it as dependent variable and harvest and variety as independent factors. On the other hand the stalk sugar content and ethanol production data were analyzed employing one-way analysis of variance and Bonferroni corrections for multiple comparisons. The analysis was done for each variety separately having the data as dependent variable and the harvest as independent factor. This methodology was employed as the experimental data was obtained by analyzing two subsamples of a composite sample of pulverized material from each variety. Both analyses of variance were done employing Stata version 9.2. The sugar distribution data was used to identify similar groups of samples employing principal components using MVSP Plus version 3.1.

\section{Results}

\subsection{Fresh stalk biomass productivity}

The fresh stalk biomass productivity data for the five sweet sorghum varieties and the three harvests for each experimental unit are shown in Table 1. The two way analysis of variance summary is given in Table 2. It is clearly seen that a) the two independent factors harvest and 
variety and their interaction were significant, and b) in all varieties lower first harvest productivity was observed. Top 76-6 led the group in total biomass productivity with about 118 $\mathrm{Mg}$ per ha for the three harvests; Sugar Drip showed the lowest figure close to $79 \mathrm{Mg}$ per ha.

\subsection{Stalk sugar content and productivity and individual sugar distribution}

The average stalk sugar content at harvest on wet basis of two sub-samples of pulverized sweet sorghum stalk is shown in Table 3 for each sweet sorghum variety and for the three harvests. The average stalk moisture among varieties at harvest did not change drastically, it was $75.87 \% \pm$ $3.91,74.88 \pm 3.91$ and $77.49 \pm 5.93$ for the first harvest and first and second ratoon crops respectively, so that expressing the sugar content on wet basis, which is commonly done, presents no problem. Table 4 lists the Bonferroni adjusted values of the difference among the means. It can be seen that the difference was significant, that is below the $5.0 \%$ level, between the first and the second ratoon crops, with the exception of Umbrella in which the difference was above this level. The difference between the first cut and the first ratoon was not significant, with the exception of M81-E in which the difference was significant at the $0.1 \%$ level. Looking at the average values for all varieties in the last column of Table 3 it can be concluded that the sugar content tended to drop drastically for the second ratoon crop.

Total sugar productivity was calculated from the fresh stalk yield and the fresh stalk sugar content data. Sugar productivity increased for the first ratoon crop and decreased drastically for the second ratoon crop. The reason being that for the second ratoon crop the stalk sugar content was much lower that the first cut and ratoon crops. Umbrella had the highest sugar productivity, 10.16 Mg per ha per year, followed by Top 76-6, 9.57 Mg per ha per year.

The individual sugar distribution data are shown in Table 5. With the exception of Umbrella the rest of sweet sorghum varieties had an atypical sugar distribution for the second ratoon crop. The sucrose content decreased and the reducing sugars increased.

We analyzed our individual sugar distribution data by principal components in order to identify groups according to the following indicators: a) sucrose, glucose and fructose proportions, b) the ratio between glucose and fructose, c) the ratio between reducing sugars and sucrose, and d) total sugar content. The results are shown in Figure 2. It is easily seen that the first principal component PC1, or horizontal axis, explaining $96 \%$ of the total variation, is able to separate and 
form a different group for second ratoon samples of four of the five sweet sorghum varieties, with exception of Umbrella, which make them different from the rest.

Figure 3 shows the relationship between stalk sugar content and the ratio between reducing sugars and sucrose. It is observed that for first cut samples there was a linear inverse relationship between variables, meaning that a lower ratio induced higher sugar content. The linear trend was weaker for ratoon samples.

\subsection{Ethanol fermentation}

The average ethanol production data employing simultaneous sugar extraction and fermentation of two sub-samples of pulverized sweet sorghum stalk are presented in Table 6. The second column lists for all sweet sorghum varieties and different harvests the experimental values expressed as $\mathrm{g}$ of ethanol per $\mathrm{kg}$ of initial dry solid particles. Umbrella and Top 76-6 produced more ethanol than the other three varieties. Table 7 lists the Bonferroni adjusted values of the difference among the means. It can be seen that the difference was not significant with the exception of: a) the first and second ratoon crop for Sugar Drip which was significant at the 3.8 $\%$ level, and b) the first cut with the second ratoon at the $2.9 \%$ level and the first ratoon with the second ratoon at the $3.6 \%$ level for Top 76-6.

We have also calculated the ethanol yield in terms of $g$ of ethanol produced per $g$ of sugar utilized. Such estimation needs to include in the calculations the extent of sugar extraction from the solid particles. This was done as follows, we estimated for both duplicates of each fermented sample the maximum ethanol yield that could be obtained for each sweet sorghum variety, taking into account a) its initial sugar content, b) a total sugar extraction from the solid particles, and c) 0.51 as the theoretical amount of ethanol produced from hexoses by yeast. The results of this calculation are listed in the third column in Table 6 which give for each variety and harvest the maximum amount of ethanol in $\mathrm{g}$ of ethanol per $\mathrm{kg}$ of initial dry solid particles. The fourth column in Table 6 lists, as \%, the experimental ethanol value divided by the calculated maximum ethanol amount. We can see that higher values of simultaneous sugar extraction and fermentation were obtained with Top 76-6. The overall process efficiency for the first cut was close to $90 \%$ of the maximum value and decreased to about $76 \%$ for the ratoon crops. The extracted sugar was not fermented completely, consumption was $95.29 \% \pm 1.32,93.55 \% \pm 5.92$ and $86.84 \% \pm 4.98$ 
for the first cut, first and second ratoon crops respectively, and significantly the remaining sugar after fermentation was essentially fructose.

Ethanol productivity data are presented in Figure 4 . The low productivity obtained in the first cut was due to the poor stalk biomass produced per ha, and in the second ratoon was due to the low stalk sugar content. Top 76-6 gave the best annual productivity with 4,837 liters per ha, of which $64 \%$ was obtained in the first ratoon crop.

\section{Discussion}

\subsection{Fresh stalk biomass productivity}

The experiments were done in order to find out the proper time to sow in order to achieve an optimum full year production cycle by having multiple harvests. In our previous publication [8] the same varieties at the same site planted in 2011 and 2012 were sowed in the middle of January with harvest in April all in the dry season, and ratoon crops in July and November during the rainy season. In the present article we planned ratoon crops during the dry season, hence the planting schedule was modified and sowing was done in July during the rainy season with harvests in October, and ratoon crops in February and May during the dry season. A summary of the planting schemes is shown in Table 8 including a qualitative appraisal of the stalk biomass productivity results.

It can be observed for both experiments that a lower than expected fresh stalk biomass productivity was obtained when plant development and harvest took place during the rainy season, irrespective if it was the first harvest or the ratoon crops. Other factors might have been involved associated with a precipitation increase during this period: a) an increase in daily cloud cover affecting solar radiation intensity and $b$ ) a more prevalent plant damage by soil microbial pathogens and pests.

Nevertheless, precipitation was a significant possible cause for this effect. Heavy precipitation in short tropical rain storms accompanied by heavy wind gusts were common during the rainy season on the experimental site. However extended waterlogging for several days or weeks did not occur as the soil exhibited adequate drainage, but short periods of soil waterlogging did indeed take place frequently. In general, the negative effect observed caused a thinner and shorter stalk although no data was taken on stalk measurements. 
It is known that sweet sorghum development is affected by different soil moisture regimes [10] although most research done has focused on scarce water availability or drought conditions [1117]. However, two review articles comment in general on the negative effects of waterlogging effects on the agricultural productivity of sorghum [18-19]. On the other hand, a study [20] investigated the effect of waterlogging in pots for 20 days on Wray, Keller and Bailey sweet sorghum cultivars and forage sorghum hybrid. The extensive flooding reduced plant height, leaf area, photosynthetic and transpiration rates. In a second study [21] flooding was induced in Wray, a sweet sorghum variety, and a multipurpose sorghum cultivar at three plant development stages, early vegetative, early reproductive and mid reproductive stages. Plant height, stem diameter, leaf area and dry weight, shoot dry weight, primary root length and root dry weight of both cultivars were significantly reduced by flooding at the early vegetative and reproductive stages, but not at the mid reproductive stage. At harvest, flooding at the early stages reduced the stalk yield of both cultivars. A third study [22] found that leaf dry weight and area, number of node per stalk, shoot dry weight, and stalk yield were reduced for Wray, Keller and Bailey sweet sorghum cultivars subjected to flooding after 30 days of plant emergence, but not later on. Such findings showed that the waterlogging negative effect on sweet sorghum plant productivity depends on the growth stage that it takes place, although no detailed discussion was provided related to the flooding time period. It has been known for some time that sweet sorghum recovers from short waterlogging conditions [23] fact that was experienced also for the sweet sorghum Wray variety in Indonesia [24]. The lower than expected first harvest fresh stalk biomass productivity that we observed in this experiment might have been caused then by short waterlogging periods.

\subsection{Stalk sugar content, productivity and individual sugar distribution}

There was no significant difference between the stalk sugar content in the first cut and first ratoon crop with the exception of M81-E, see Table 4. Similar results have been published by Erickson et al [25] for three sweet sorghum cultivars planted in Florida and found that sugar content, measured as juice Brix values, for all cultivars was similar for the first cut and ratoon crop. However other authors have reported opposite results, Han et al [26] for three sweet sorghum varieties planted in Louisiana found for the ratoon crop a drop of about 2-6 Brix units in the pressed juice compared to the first harvest. Wang et al [27] reported variable results for 
sweet sorghum hybrid cultivars planted in Lubbock, Texas, in most of them the relationship between total sugar and dry mass increased, however there were a few where the inverse happened. It seems then that an increase or a decrease will depend on the variety and the plantation site.

The stalk sugar content decreased significantly for the second ratoon crop. We found the same result in our previous work [8] as indicated in Table 8. It seems then that the sugar drop happens irrespective of the time in the year that the second ratoon crop takes place, either under dry weather or during the rainy season, so there is really no evidence of any effect from an environmental variable like excess precipitation causing short time flooding. We do not have a clear explanation for this drastic sugar decrease and unfortunately, as known to us, there is no similar data available in the literature to compare it. The second ratoon crop developed normally with an acceptable stalk biomass yield. As discussed below a physiological effect seemed more possible.

Sugar accumulation in the stems is regulated by a system of enzymes as discussed recently [28,29]. It seems that a low soluble acid invertase (SAI) activity coupled with a higher sucrose phosphate synthase (SPS) can promote higher sugar contents in the stem. A significant linear correlation was found between glucose plus fructose contents and SAI activity for various cultivars, also between sucrose content and the difference in activities between SPS and SAI. We indeed found a linear inverse relationship between stalk sugar content and the amount of reducing sugars at harvest as shown in Figure 3.

High or low sucrose content at harvest might imply high or low total sugar content. The second ratoon crop had the shortest development cycle being harvested after only 107 days, time on which the grain reached the soft dough stage. It is possible then that the second ratoon crop required more time to reach full maturation. Figure 2 shows that this group of samples was different from the other two groups, the first cut and the first ratoon samples, in terms of their individual sugar contents.

The sweet sorghum production scheme consisting of various harvests per year, either one or two ratoon crops, can be compared in terms of sugar productivity with the experiments by Han et al [26] with sweet sorghum varieties planted in Louisiana and including one ratoon crop, an average value of approximately 9.6 Mg per ha per year can be calculated from their data. This figure is similar to our present results, for example, Umbrella and Top 76-6 with two ratoon 
crops had sugar productivities of approximately 10.2 and $9.6 \mathrm{Mg}$ per ha per year respectively. In our previous publication [8] the same varieties at the same site planted during the dry season in 2011 and 2012 with two ratoon crops showed the highest productivity also, however, the total sugar productivity then was below $9 \mathrm{Mg}$ per ha per year. On the other hand, the year-round scheme for sweet sorghum can also be compared with commercial sugarcane production in Brazil. Recent typical figures for this country are a fresh stalk productivity of $85 \mathrm{Mg}$ per ha per year with $14.5 \%$ sugar content, which gives $12.32 \mathrm{Mg}$ of sugar per ha per year [30]. We believe that this productivity can be reached with sweet sorghum, specifically with Top76-6 and Umbrella, by further experimentation.

All of these results suggest that ratoon crops have to be managed differently form first cuts. Ratoon crops might need more time in the field in order to reach maximum sucrose content and higher total sugars. Harvest time should not be determined by grain maturity characteristics as it is usually done for first cuts, but instead, a juice sample from the stem should be taken for each variety and sugar analysis should be performed. It is possible then that harvesting the second ratoon crop prematurely determined only by grain maturity characteristics might have caused the low sugar content data and the atypical sugar distribution found.

\subsection{Ethanol fermentation}

The use of $\mathrm{g}$ of ethanol per $\mathrm{kg}$ of initial dry solid particles to express ethanol production has been commonly used in solid substrate fermentation of sweet sorghum particles [31-36] and is also useful in solid suspended fermentations where sugar is extracted from the solid particles and fermented by yeast in simultaneous fashion [8,9]. Results on these units can be compared to the corresponding figure obtained from a reference sweet sorghum cultivar containing $500 \mathrm{~g}$ of fermentable hexoses and $500 \mathrm{~g}$ of structural carbohydrates per kg of dry stalk. Employing the theoretical ethanol yield of $0.51 \mathrm{~g}$ of ethanol per $\mathrm{g}$ of hexose, the maximum yield from the hexoses gives $255 \mathrm{~g}$ of ethanol per kg of dry matter. Our calculations for the maximum yield, showed in the third column of Table 6 were most below this figure; however the first cut and first ratoon for Sugar Drip and Umbrella and the first ratoon for Top 76-6 were in the range of 204 to $260 \mathrm{~g}$ of ethanol per $\mathrm{kg}$ of dry matter. On the other hand the overall sugar extraction and conversion to ethanol data, showed in the fourth column of Table 6, indicated that only for M81E and Top 76-6 first cuts the efficiency was above $85 \%$ of the maximum possible. 
The final ethanol content in the flask was low enough to avoid yeast inhibition, hence, the differences in ethanol production found among sweet sorghum varieties might have originated either from inhibitors in certain sweet sorghum varieties or by differences in the lignocellulosic fraction structure and chemical composition for each variety which might influenced sugar extraction rates and extent [37]. The possible fermentation inhibitors that have been mentioned are organic acids: aconitic acid which is present in sweet sorghum juice and lactic and acetic acids which are microbial products of homo- and hetero-bacteria active during handling and storage of sweet sorghum stalks or billets [38]. Aconitic acid is metabolically produced during plant development and decreases at harvest [39]. There is limited information, according to our knowledge, on the aconitic acid content of different varieties and hybrids, a recent article [40] reports a value of $18 \mathrm{~g} / \mathrm{L}$ in sweet sorghum juice. Klasson [41] has published some details on the inhibition in experiments employing $80 \mathrm{~g} / \mathrm{L}$ sweet sorghum juice in fermentations with the addition of acetic, lactic and aconitic acids. He found inhibition in fermentations containing above $2 \mathrm{~g} / \mathrm{L}$ of acetic acid. Lower levels and all levels of lactic and aconitic acids (1-5 g/L) were not detrimental to ethanol production. However, higher levels of aconitic acid are possible in raw sweet sorghum juice [40] and it could become critical in concentrated juice and VHG, very high gravity, fermentations. The undissociated acids seem to be the main culprits [41].

The individual sugar variation among varieties might not be a factor influencing ethanol production, as it is well known that glucose is a preferred uptake substrate for yeasts over fructose and sucrose [42]. Sucrose is hydrolyzed by invertase in the periplasmic space of the yeast cell, which is the space between the cell wall and the cytoplasmic membrane, into glucose and fructose, which then enter the cell by facilitated diffusion [43, 44]. Ethanol producing yeasts also produce extracellular invertases which usually are subjected to glucose repression and the liberated glucose and fructose in the fermentation broth are eventually transported into the cell by the same transporters. In a mixture of sucrose, glucose and fructose, for many types of yeast, glucose will be consumed first, then sucrose and finally fructose [44]. In our fermentations fructose was the only sugar remaining suggesting a relatively slower transport into the cell. This fact has also been reported before for sweet sorghum fermentations [45].

The best annual productivity was shown by Top 76-6 with 4,837 liters per ha, of those 718 were for the first cut, and 3,116 and 1,003 for the first and second ratoon crops respectively. 
With sugarcane in Brazil current figures estimate around 7,580 liters of ethanol per ha per year [30].

\section{Conclusion}

The planting scheme of sowing and harvesting in the rainy season and ratoon crops during the dry season induced in five sweet sorghum varieties the following results. The fresh stalk biomass productivity was different among varieties and harvests. All varieties had a lower than expected first harvest productivity and Top 76-6 showed the best value, $118 \mathrm{Mg}$ per ha for the three harvests. Short waterlogging periods during the rainy period might have been the cause. The stalk sugar content dropped drastically for the second ratoon crop in all varieties and with the exception of Umbrella, they also had an atypical sugar distribution, as sucrose content decreased and reducing sugars increased. A premature harvest of the second ratoon crop might have been the possible cause. More ethanol was extracted and fermented simultaneously in pulverized stalk samples of Umbrella and Top 76-6. The latter variety showed the best overall process efficiency, close to $90 \%$ for the first cut and about $76 \%$ for the ratoon crops, and the best annual productivity with 4,837 liters per ha. Fructose was the only remaining sugar after fermentation. Fresh stalk biomass, sugar and ethanol productivities in the present planting scheme were improved over those previously obtained [8] with the same varieties at the same site in which sowing and harvesting was done in the dry season and the ratoon crops developed during the rainy period. However, the unexpected low sugar content of the second ratoon crop in our present experiment suggests that, at least in the tropics, only one ratoon crop might be advisable.

\section{Acknowledgements}

We appreciate the suggestions and constructive criticism of three anonymous reviewers. This work was partially financed by a grant from the USDA Food for Progress 10 Program and by project FONACYT 09-2011 of the Guatemala National Science Council (CONCYT).

\section{References}


[1] W.L. Rooney, J. Blumenthal, B. Bean, J.E. Mullet, Designing sorghum as a dedicated bioenergy feedstock, Biofuels Bioprod. Bioref. 1 (2007) 147-57.

[2] A. Almodares, M.R. Hadi, Production of bioethanol from sweet sorghum: A review, Afr. J. Ag. Res. 4 (2009) 772-80.

[3] Z. Xin, M.L. Wang, Sorghum as a versatile feedstock for bioenergy production, Biofuels 2 (2011) 577-88.

[4] M. Calviño, J. Messing, Sweet sorghum as a model system for bioenergy crops, Curr. Op. Biotech. 23 (2012) 323-29.

[5] W. Zegada-Lizarazu, A. Monti, Are we ready to cultivate sweet sorghum as a bioenergy feedstock? A review on field management practices, Biomass Bioenerg. 40 (2012) 1-12.

[6] J. Woods, The potential for energy production using sweet sorghum in southern Africa, Energ. Sustain. Develop. 5 (2001) 31-38.

[7] L. Cutz, S. Sánchez-Delgado, U. Ruiz-Rivas, D. Santana, Bioenergy production in Central America: integration of sweet sorghum into sugar mills, Renew. Sustain. Energ. Rev. 25 (2013) $529-42$.

[8] C. Rolz, R. de León, A.L. Mendizábal de Montenegro, R. Cifuentes, Ethanol from sweet sorghum in a year-round production cycle, Biomass Conver. Bioref. 4 (2014) 341-50.

[9] R. Cifuentes, R. Bressani, C. Rolz, The potential of sweet sorghum as a source of ethanol and protein, Energ. Sustain. Develop. 21 (2014) 13-19.

[10] W. Zegada-Lizarazu, A. Zatta, A. Monti, Water uptake efficiency and above- and belowground biomass development of sweet sorghum and maize under different water regimes, Plant Soil 351 (2012) 47-60.

[11] A. Almodares, R.H. Hotjatabady, E. Mirniam, Effects of drough stress on biomass and carbohydrate contents of two sweet sorghum cultivars, J. Environ. Biol. 34 (2013) 585-89.

[12] Y. Besufekad, K. Bantte, Evaluation and Association Mapping for Drought Tolerance in Sorghum [Sorghum Bicolor (L.) Moench], Global J. Sci. Frontier Res. Agr. Veter. 13 (2013) 5.

[13] B. Hao, Q. Xue, B.W. Bean, W.L. Rooney, J.D. Becker, Biomass production, water and nitrogen use efficiency in photoperiod-sensitive sorghum in the Texas High Plains, Biomass Bioenerg. 62 (2014) 108-16. 
[14] P. Munirathnam, K.A. Kumar, P.S. Rao, Performance of Sweet Sorghum Varieties and Hybrids During Post Rainy Season (maghi) in Vertisols of Scarce Rainfall Zone in Andhra Pradesh, Sugar Tech. 15 (2013) 271-77.

[15] C.C. Ogbaga, P. Stepien, G.N. Johnson, Sorghum varieties adopt strongly contrasting strategies in respone to drought, Physiol. Plant. 152 (2014) 389-401.

[16] J. Schittenhelm, S. Schroetter, Comparison of Drought Tolerance of Maize, Sweet Sorghum and Sorghum-Sudangrass Hybrids, J. Agron. Crop Sci. 200 (2014) 46-53.

[17] W-F. Wang, Y-Z. Zong, S-Q Zhang, Water- and Nitrogen-use Efficiencies of Sweet Sorghum Seedlings are Improved under Water Stress, Internat. J. Agr. Biol. 16 (2014) 285-92.

[18] R. Rao, Y. Li, Managing on flooding effects on growth of vegetables and selected field crops, Hort. Technol. 13 (2003) 610-16.

[19] A. Maryam, S. Nasreen, A review: waterlogging effects on morphological, anatomical, physiological and biochemical attributes on food and cash crops, Internat. J. Water Resourc. Environ. Sci. 1 (2012) 113-120.

[20] A. Promkhambut, A. Younger, A. Polthanee, C. Akkasaeng, Morphological and physiological responses of sorghum to waterlogging, Asian J. Plant Sci. 9 (2010) 183-93.

[21] A. Promkhambut, A. Polthanee, C. Akkasaeng, A. Younger, A flood-free period combined with early planting is required to sustain of pre-rice sweet sorghum, Acta Agr. Scand. Section B - Soil Plant Sci. 61 (2011) 345-55.

[22] A. Promkhambut, A. Polthanee, C. Akkasaeng, A. Younger, Growth, yield and aerenchyma formation of sweet and multipurpose sorghum as affected by flooding at different growth stages, Aus. J. Crop Sci. 5 (2011) 954-65.

[23] J.R. Pardales, Y. Kono, A. Yamauchi, Response of the different root system components of sorghum to incidence of waterlogging, Environ. Exp. Bot. 31 (1991) 107-15.

[24] N. Tsuchihashi, Y. Goto, Year-round cultivation of sweet sorghum through a combination of seed and ratoon cropping in Indonesia savanna, Plant Prod. Sci. 11 (2008) 377-84.

[25] J.E. Erickson, Z.R. Helsel, K.R. Woodward, J.M.B. Vendramini, Y. Wang, L.E. Sollenberger, R.A. Gilbert, Planting date affects biomass and brix of sweet sorghum grown for biofuel across Florida, Agr. J. 103 (2011) 1827-33.

[26] K.J. Han, W.D. Pitman, M.W. Alison, D.L. Harrell, H.P. Viator, M.E. McCormick, K.A. Gravois, M. Kim, D.F. Day, Agronomic considerations for sweet sorghum biofuel production in 
the southcentral USA, Bioenerg. Res. 5 (2012) 748-58.

[27] M. Wang, Z. Xin, B. Tonnis, G. Farrell, D. Pinnow, Z. Chen, J. Davis, J. Yu, Y.C. Hung, G.A. Pederson, Evaluation of sweet sorghum as a feedstock by multiple harvests for sustainable bioenergy production, J. Sustain. Bioenerg. Syst. 2 (2012) 122-37.

[28] H.A. Qazi, S. Paranjpe, S. Bhargave, Stem sugar accumulation in sweet sorghum-activity and expression of sucrose metabolizing enzymes and sucrose transporters, J. Plant Physiol. 169 (2012) 605-13.

[29] L. Yang, D. Bao-qing, Z. Xiang-na, Y. Mei-qi, L. Ming, L. Gui-ying, Correlation analysis between key enzyme activities and sugar content in sweet sorghum stems at physiological maturity stage, Aus. J. Crop Sci. 7 (2013) 84-92.

[30] J.G.G. Jonker, F. van der Hilst, H.M. Junginger, O. Cavalett, M.F. Chagas, A.P.C. Faaij, Outlook for ethanol production costs in Brazil up to 2030, for different biomass crops and industrial technologies, Appl. Energ. 147 (2015) 593-610.

[31] J. Yu, X. Zhang, T. Tan, Ethanol production by solid state fermentation of sweet sorghum using thermotolerant yeast strain, Fuel Process. Technol. 89 (2008) 1056-59.

[32] F. Shen, R. Liu, Research on Solid-State Ethanol Fermentation Using Dry Sweet Sorghum Stalk Particles with Active Dry Yeast, Energ. Fuels 23 (2009) 519-25.

[33] Y-J. Kwon, F. Wang, C-Z. Liu, Deep-bed solid state fermentation of sweet sorghum stalk to ethanol by thermotolerant Issatchenkia orientalis IPE 100, Bioresour. Technol. 102 (2011) 11262-65.

[34] J. Li, S. Li, B. Han, M. Yu, G. Li, Y. Jiang, A novel cost-effective technology to convert sucrose and homocelluloses in sweet sorghum stalks into ethanol, Biotechnol. Biofuels 6 (2013) 174.

[35] H-Z Chen, Z-H Liu, S-H Dai, A novel solid state fermentation coupled with gas stripping enhancing the sweet sorghum stalk conversion performance for bioethanol, Biotechnol. Biofuels 7 (2014) 53.

[36] R. Du, J. Yan, Q. Feng, P. Li, L. Zhang, S. Chang, S. Li, A Novel Wild-Type Saccharomyces cerevisiae Strain TSH1 in Scaling-Up of Solid-State Fermentation of Ethanol from Sweet Sorghum Stalks, PLoS ONE 9 (4) (2014) e94480. doi:10.1371. 
[37] M. Li, S. Feng, L. Wu, Y. Li, C. Fan, R. Zhang, W. Zou, Y. Tu, H-C Jing, S. Li, L. Peng, Sugar-rich sweet sorghum is distinctively affected by wall polymer features for biomass digestibility and ethanol fermentation in bagasse, Bioresour. Technol. 167 (2014) 14-23.

[38] X. Wu, S. Staggenborg, J.L. Propheter, W.L. Rooney, J. Yu, D. Wang, Features of sweet sorghum juice and their performance in ethanol fermentation, Ind. Crops Prod. 31 (2010) 164170.

[39] A. Almodares, M. Ranjbar, M.R. Hadi, Effects of nitrogen treatments and harvesting stages on the aconitic acid, invert sugar and fiber in sweet sorghum cultivars, J. Environ. Biol. 31 (2010) 1001-1005.

[40] V. Larnaudie, E. Rochón, M.D. Ferrari, C. Lareo, Energy evaluation of fuel bioethanol production from sweet sorghum using very high gravity (VHG) conditions, Renew. Energy 88 (2016) 280-287.

[41] K.T. Klasson Impact of Potential Fermentation Inhibitors Present in Sweet Sorghum Sugar Solutions, Sugar Tech (2016) In press, DOI 10.1007/s12355-016-0433-2.

[42] N.J. Berthels, R.R. Cordero-Otero, F.F. Bauer, J.M. Thevelein, I.S. Pretorius, Discrepancy in glucose and fructose utilisation during fermentation by Saccharomyces cerevisiae wine yeast strains, FEMS Yeast Res. 4 (2004) 683-89.

[43] M. Perez, K. Luyten, R. Michel, C. Riou, B. Blondin, Analysis of Saccharomyces cerevisiae hexose carrier expression during wine fermentation: both low-and high-affinity Hxt transporters are expressed, FEMS Yeast Res. 5 (2005) 351-61.

[44] W.L. Marques, V. Raghavendran, B.U. Stambuk, A.K. Gombert, Minireview Sucrose and Saccharomyces cerevisiae: a relationship most sweet, FEMS Yeast Research, 16 (2016) fov107. [45] W. Zegada-Lizarazu, A. Monti, An integrated approach to harvest and storage of sweet sorghum at farm scale, Bioenerg. Res. 8 (2015) 450-58. 
Table 1. Fresh stalk biomass productivity in $\mathrm{Mg}$ per ha

\begin{tabular}{|ccccccc|}
\hline & Della & M81-E & Sugar Drip & Top 76-6 & Umbrella & \\
\hline First cut & $28.98 \pm 3.01$ & $30.97 \pm 7.27$ & $16.48 \pm 6.46$ & $11.93 \pm 1.39$ & $17.05 \pm 4.25$ & 21.08 \\
\hline First ratoon & $37.50 \pm 3.83$ & $36.65 \pm 6.39$ & $28.41 \pm 4.25$ & $57.39 \pm 4.59$ & $46.31 \pm 3.52$ & 41.25 \\
\hline $\begin{array}{c}\text { Second } \\
\text { ratoon }\end{array}$ & $44.89 \pm 5.29$ & $35.51 \pm 2.52$ & $34.09 \pm 3.59$ & $48.58 \pm 4.58$ & $50.00 \pm 3.35$ & 42.61 \\
\hline $\begin{array}{c}\text { Total per } \\
\text { year }\end{array}$ & 111.36 & 103.13 & 78.98 & 117.90 & 113.35 & \\
\hline
\end{tabular}

Table 2. Anova results for the stalk biomass productivity data

\begin{tabular}{|lccccc|}
\hline & Partial SS & df & MS & F & Prob > F \\
\hline Model & 9759 & 14 & 697 & 33.72 & 0.0000 \\
\hline Harvest & 5816 & 2 & 2908 & 140.67 & 0.0000 \\
\hline Variety & 1276 & 4 & 319 & 15.43 & 0.0000 \\
\hline Harvest* Variety & 2667 & 8 & 333 & 16.13 & 0.0000 \\
\hline Residual & 930 & 45 & 21 & & \\
\hline Total & 10689 & 59 & 181 & & \\
\hline
\end{tabular}

Table 3. Fresh stalk total sugar content $\%$ on wet basis (g of sugars/100g of wet stalk)

\begin{tabular}{|lcccccc|}
\hline & Della & M81-E & Sugar Drip & Top76-6 & Umbrella & Average \\
\hline First cut & $7.54 \pm 0.89$ & $7.38 \pm 0.22$ & $7.62 \pm 1.73$ & $10.36 \pm 0.28$ & $9.76 \pm 2.22$ & 8.53 \\
\hline First ratoon & $10.03 \pm 0.05$ & $10.59 \pm 0.05$ & $11.10 \pm 0.37$ & $10.88 \pm 0.07$ & $10.88 \pm 0.07$ & 10.70 \\
\hline Second ratoon & $3.81 \pm 0.27$ & $2.61 \pm 0.07$ & $3.58 \pm 0.79$ & $4.15 \pm 0.10$ & $5.54 \pm 0.30$ & 3.94 \\
\hline Average & 7.13 & 6.86 & 7.43 & 8.46 & 8.73 & \\
\hline
\end{tabular}


Table 4. Bonferroni adjusted significance of the difference among means for the stalk sugar content data

\begin{tabular}{|l|c|}
\hline & \multicolumn{2}{c|}{ Della } \\
\cline { 2 - 3 } & First cut First ratoon \\
\hline First ratoon & 0.056 \\
\hline Second ratoon & 0.018 \\
\hline \multicolumn{2}{|c|}{ M81-E } \\
\hline First ratoon & 0.001 \\
\hline Second ratoon & 0.000 \\
\hline \multicolumn{2}{|c|}{ Sugar Drip } \\
\hline First ratoon & 0.158 \\
\hline Second ratoon & 0.109 \\
\hline \multicolumn{2}{|c|}{ Top 76-6 } \\
\hline First ratoon & 0.321 \\
\hline Second ratoon & 0.001 \\
\hline \multicolumn{2}{|c|}{ Umbrella } \\
\hline First ratoon & 1.000 \\
\hline Second ratoon & 0.142 \\
\hline
\end{tabular}


Table 5. Individual sugar distribution as $\%$ of total sugar

\begin{tabular}{|lccc|}
\hline & Sucrose & Glucose & Fructose \\
\hline Della & & & \\
\hline First cut & $69.33 \pm 3.14$ & $18.56 \pm 1.53$ & $12.11 \pm 1.61$ \\
\hline First ratoon & $61.94 \pm 1.05$ & $22.11 \pm 0.40$ & $15.95 \pm 1.45$ \\
\hline Second ratoon & $46.58 \pm 0.07$ & $28.58 \pm 0.04$ & $24.83 \pm 0.11$ \\
\hline M81-E & & & \\
\hline First cut & $65.63 \pm 0.30$ & $22.47 \pm 0.05$ & $11.90 \pm 0.05$ \\
\hline First ratoon & $80.06 \pm 1.15$ & $12.99 \pm 0.49$ & $6.95 \pm 1.64$ \\
\hline Second ratoon & $22.30 \pm 8.05$ & $48.97 \pm 5.25$ & $28.74 \pm 2.80$ \\
\hline Sugar Drip & & & \\
\hline First cut & $64.16 \pm 0.75$ & $26.04 \pm 1.98$ & $9.80 \pm 1.23$ \\
\hline First ratoon & $62.96 \pm 3.25$ & $26.52 \pm 2.27$ & $10.52 \pm 0.98$ \\
\hline Second ratoon & $49.32 \pm 0.08$ & $33.48 \pm 0.60$ & $17.20 \pm 0.69$ \\
\hline Top 76-6 & & & \\
\hline First cut & $79.17 \pm 3.95$ & $12.03 \pm 2.15$ & $8.80 \pm 1.80$ \\
\hline First ratoon & $80.32 \pm 0.84$ & $11.73 \pm 0.26$ & $7.94 \pm 0.58$ \\
\hline Second ratoon & $49.41 \pm 1.20$ & $32.51 \pm 1.20$ & $18.09 \pm 0.01$ \\
\hline Umbrella & & & \\
\hline First cut & $76.81 \pm 4.17$ & $17.38 \pm 2.88$ & $5.81 \pm 1.28$ \\
\hline First ratoon & $59.29 \pm 6.22$ & $30.71 \pm 3.15$ & $10.00 \pm 3.07$ \\
\hline Second ratoon & $70.65 \pm 4.44$ & $17.96 \pm 3.30$ & $11.39 \pm 1.14$ \\
\hline
\end{tabular}


Table 6. Experimental ethanol production in $\mathrm{g}$ ethanol per $\mathrm{kg}$ of initial dry stalk particles and comparison with respect of the maximum value

\begin{tabular}{|lccc|}
\hline \multicolumn{4}{|c|}{ Della } \\
\hline First cut & Experimental ethanol & Maximum ethanol & \% of Maximum \\
\hline First ratoon & $60.51 \pm 3.25$ & $189.20 \pm 1.07$ & $31.99 \pm 1.90$ \\
\hline Second ratoon & $40.05 \pm 6.12$ & $74.18 \pm 12.69$ & $54.08 \pm 1.00$ \\
\hline \multicolumn{4}{|c|}{ M81-E } \\
\hline First cut & $141.08 \pm 40.63$ & $164.29 \pm 6.88$ & $86.47 \pm 28.35$ \\
\hline First ratoon & $99.18 \pm 0.89$ & $194.87 \pm 0.60$ & $50.90 \pm 0.61$ \\
\hline Second ratoon & $29.92 \pm 6.76$ & $47.60 \pm 3.74$ & $62.49 \pm 9.28$ \\
\hline \multicolumn{4}{|c|}{ Sugar Drip } \\
\hline First cut & $89.79 \pm 23.07$ & $208.49 \pm 41.11$ & $45.03 \pm 19.44$ \\
\hline First ratoon & $148.56 \pm 8.84$ & $259.45 \pm 0.47$ & $57.26 \pm 3.51$ \\
\hline Second ratoon & $59.20 \pm 14.63$ & $78.25 \pm 22.54$ & $76.13 \pm 3.23$ \\
\hline & & Top 76-6 \\
\hline First cut & $160.54 \pm 11.36$ & $179.62 \pm 3.56$ & $89.45 \pm 8.09$ \\
\hline First ratoon & $155.06 \pm 17.40$ & $203.96 \pm 9.06$ & $75.91 \pm 5.16$ \\
\hline Second ratoon & $89.08 \pm 2.31$ & $117.02 \pm 12.15$ & $76.43 \pm 5.94$ \\
\hline & \multicolumn{4}{|c|}{ Umbrella } \\
\hline First cut & $138.17 \pm 58.73$ & $209.47 \pm 69.84$ & $64.89 \pm 6.40$ \\
\hline First ratoon & $149.28 \pm 47.34$ & $257.80 \pm 33.37$ & $57.19 \pm 10.96$ \\
\hline Second ratoon & $114.17 \pm 1.17$ & $195.22 \pm 45.59$ & $60.05 \pm 13.42$ \\
\hline
\end{tabular}


Table 7. Bonferroni adjusted significance of the difference among means for the ethanol production data

\begin{tabular}{|l|c|}
\hline & \multicolumn{2}{c|}{ Della } \\
\cline { 2 - 3 } & First cut First ratoon \\
\hline First ratoon & 0.708 \\
\hline Second ratoon & 0.078 \\
\hline \multicolumn{2}{|c|}{ M81-E } \\
\hline First ratoon & 0.529 \\
\hline Second ratoon & 0.056 \\
\hline \multicolumn{2}{|c|}{ Sugar Drip } \\
\hline First ratoon & 0.115 \\
\hline Second ratoon & 0.487 \\
\hline \multicolumn{2}{|c|}{ Top 76-6 6} \\
\hline First ratoon & 1.000 \\
\hline Second ratoon & 0.029 \\
\hline \multicolumn{2}{|c|}{ Umbrella } \\
\hline First ratoon & 1.000 \\
\hline Second ratoon & 1.000 \\
\hline
\end{tabular}


Table 8. Summary of stalk biomass productivity, sugar content and distribution for the three harvests and comparison with previous work (8)

\begin{tabular}{|c|c|c|c|c|c|c|}
\hline Month & January & February & April & July & October & November \\
\hline Precipitation & Dry & Dry & Dry & Rain & Rain & Rain \\
\hline $\begin{array}{l}\text { Previous } \\
\text { work }\end{array}$ & Sowing & & Harvest & $\begin{array}{l}\text { Ratoon } \\
\text { harvest }\end{array}$ & & $\begin{array}{l}\text { Ratoon } \\
\text { harvest }\end{array}$ \\
\hline $\begin{array}{c}\text { Stalk } \\
\text { biomass } \\
\text { productivity }\end{array}$ & & & Normal & $\begin{array}{c}\text { Lower than } \\
\text { expected }\end{array}$ & & $\begin{array}{c}\text { Lower than } \\
\text { expected }\end{array}$ \\
\hline $\begin{array}{c}\text { Stalk sugar } \\
\text { content }\end{array}$ & & & Normal & Normal & & $\begin{array}{c}\text { Lower than } \\
\text { expected }\end{array}$ \\
\hline $\begin{array}{c}\text { Sugar } \\
\text { distribution }\end{array}$ & & & Normal & Normal & & $\begin{array}{c}\text { Not } \\
\text { determined }\end{array}$ \\
\hline $\begin{array}{c}\text { Present } \\
\text { work }\end{array}$ & & $\begin{array}{l}\text { Ratoon } \\
\text { harvest }\end{array}$ & $\begin{array}{l}\text { Ratoon } \\
\text { harvest }\end{array}$ & Sowing & Harvest & \\
\hline $\begin{array}{c}\text { Stalk } \\
\text { biomass } \\
\text { productivity }\end{array}$ & & Normal & Normal & & $\begin{array}{c}\text { Lower than } \\
\text { expected }\end{array}$ & \\
\hline $\begin{array}{c}\text { Stalk sugar } \\
\text { content }\end{array}$ & & Normal & $\begin{array}{c}\text { Lower than } \\
\text { expected }\end{array}$ & & Normal & \\
\hline $\begin{array}{c}\text { Sugar } \\
\text { distribution }\end{array}$ & & $\begin{array}{l}\text { Lower } \\
\text { sucrose }\end{array}$ & $\begin{array}{l}\text { Lower } \\
\text { sucrose }\end{array}$ & & Normal & \\
\hline
\end{tabular}


Figure 1. Average (line with circles), maximum (upper dashed line) and minimum (lower dashed line) temperatures during the yearly production cycle. Average monthly precipitation on the right vertical axis (dash dot line). The horizontal bars below indicate the plant cycle length for each harvest, the first bar, the first crop growth, the second bar, the first ratoon crop and the last bar, the second ratoon crop.
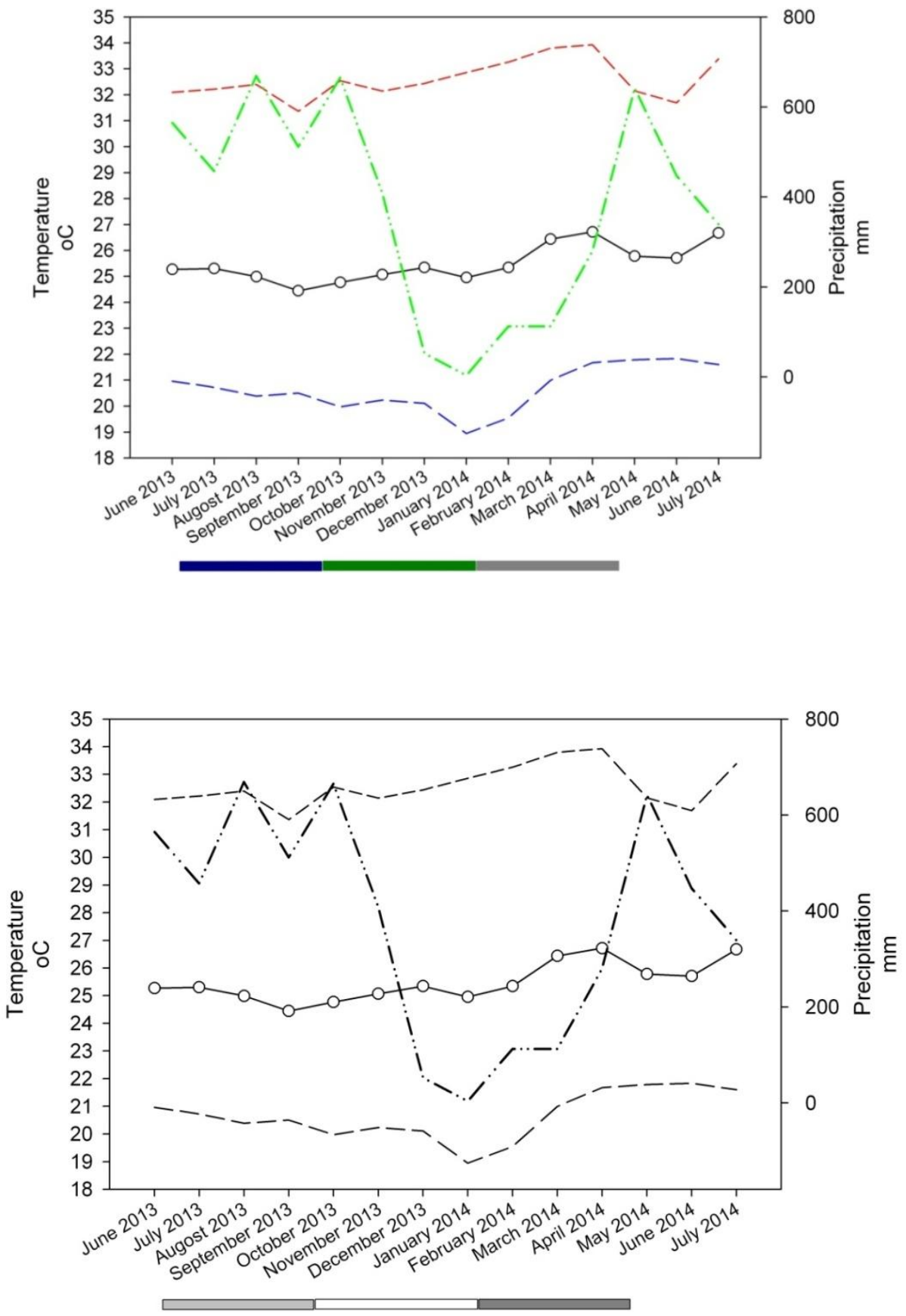
Figure 2. Principal components score diagram first and second components. Squares: first cut samples. Triangles down: first ratoon samples. Circles: second ratoon samples. Letters identify sweet sorghum varieties: D: Della. M: M81-E. S: Sugar Drip. T: Top 76-6. U: Umbrella.

\section{PCA case scores}

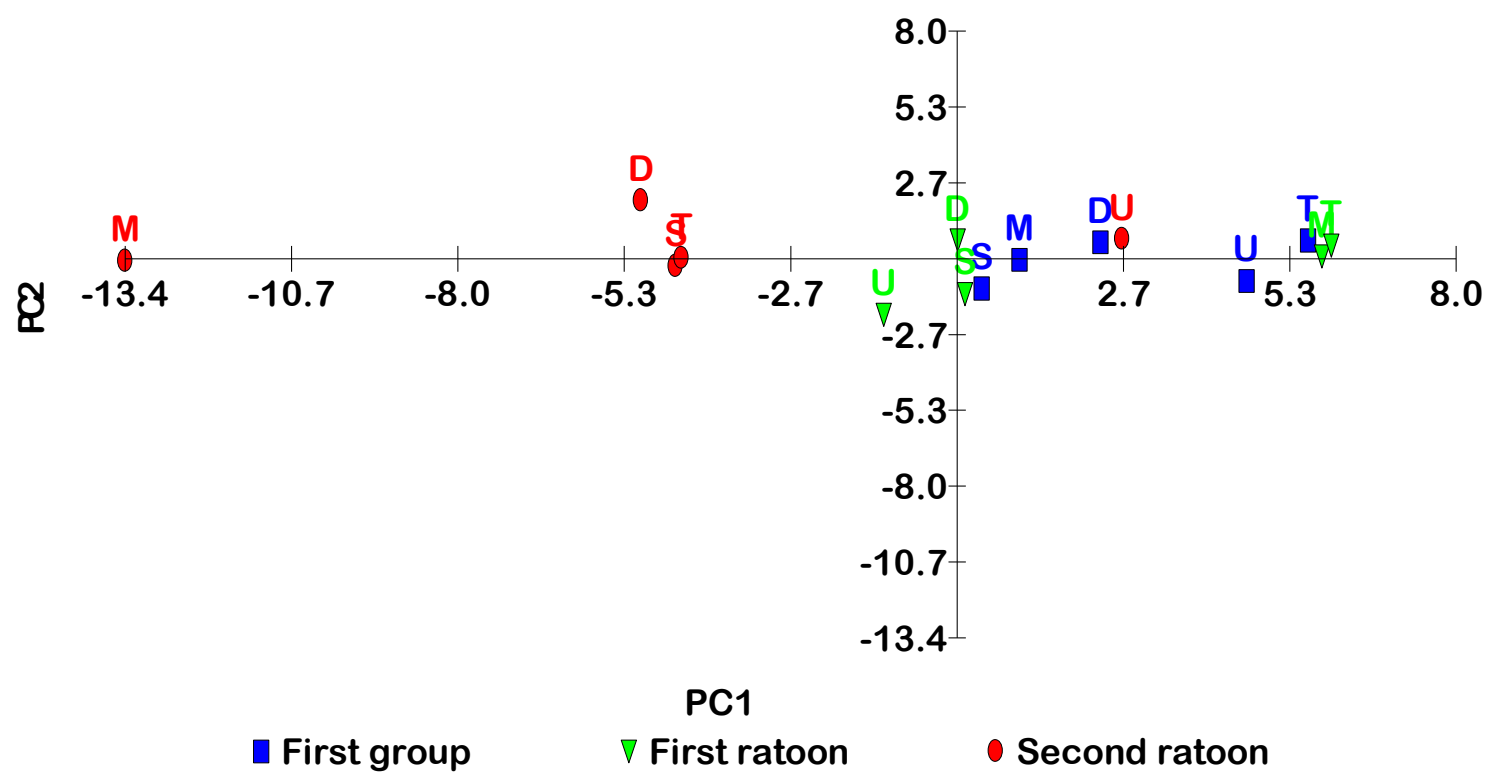

\section{PCA case scores}

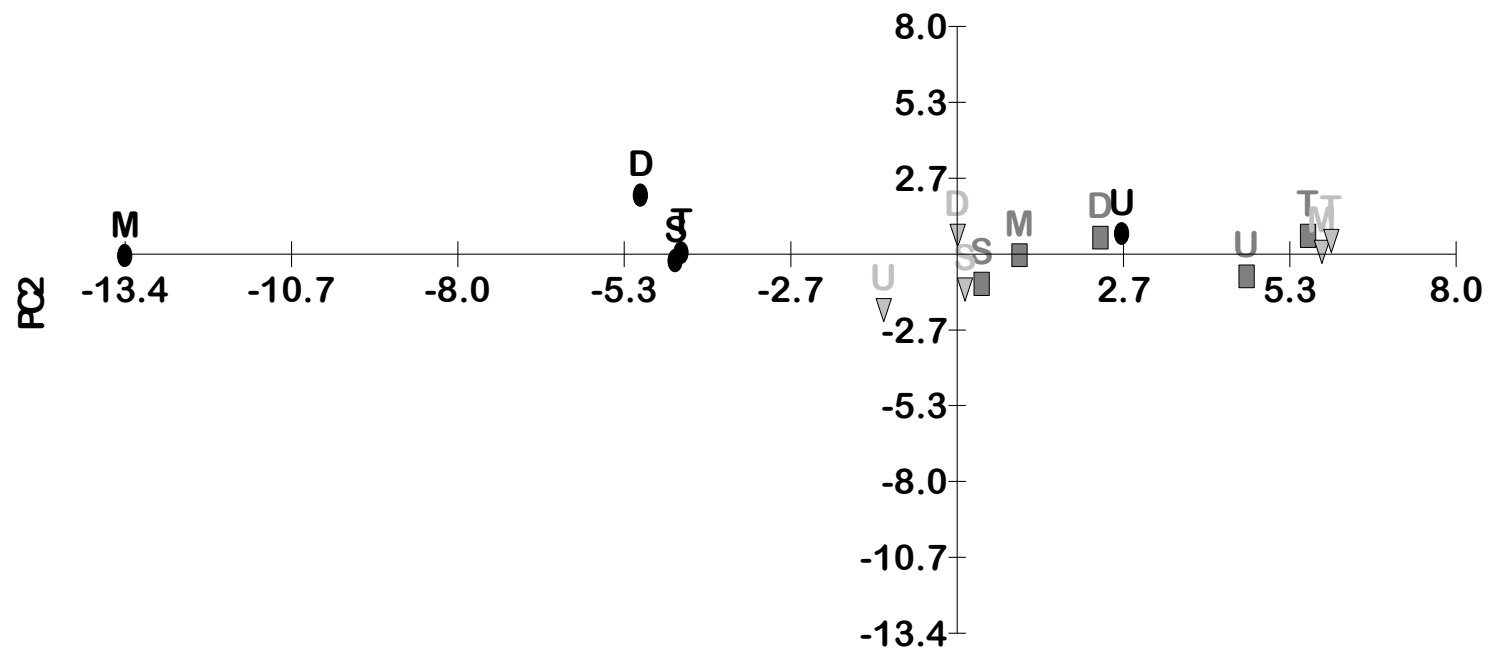

PC1

$\square$ First group

- Second ratoon 

Figure 3. Scatter diagram between the stalk sugar content in $\%$ on wet basis versus the ratio between reducing sugars over sucrose.
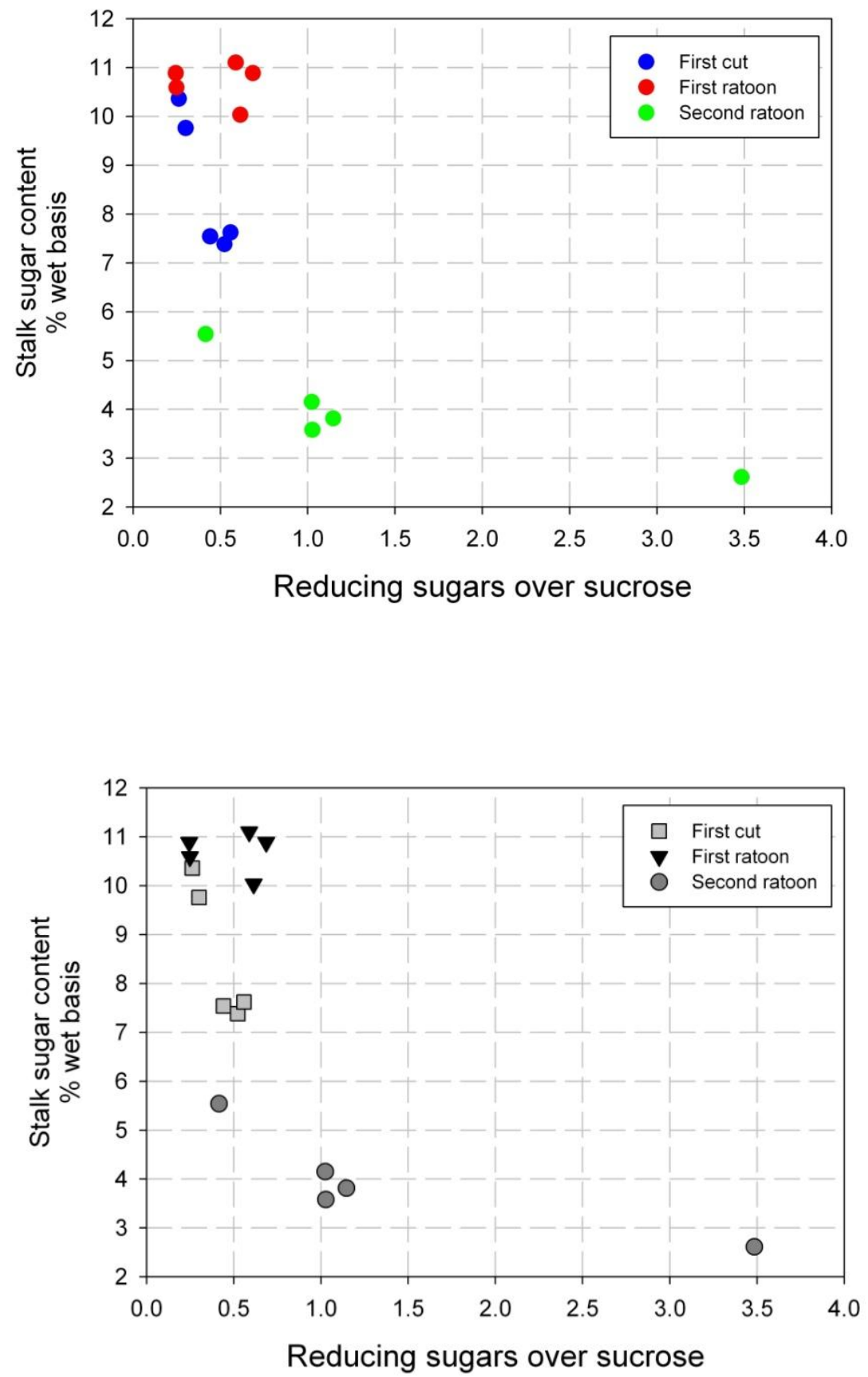
Figure 4. Ethanol productivity in liters per ha obtained from samples from the five sweet sorghum varieties and the three harvests done in the year
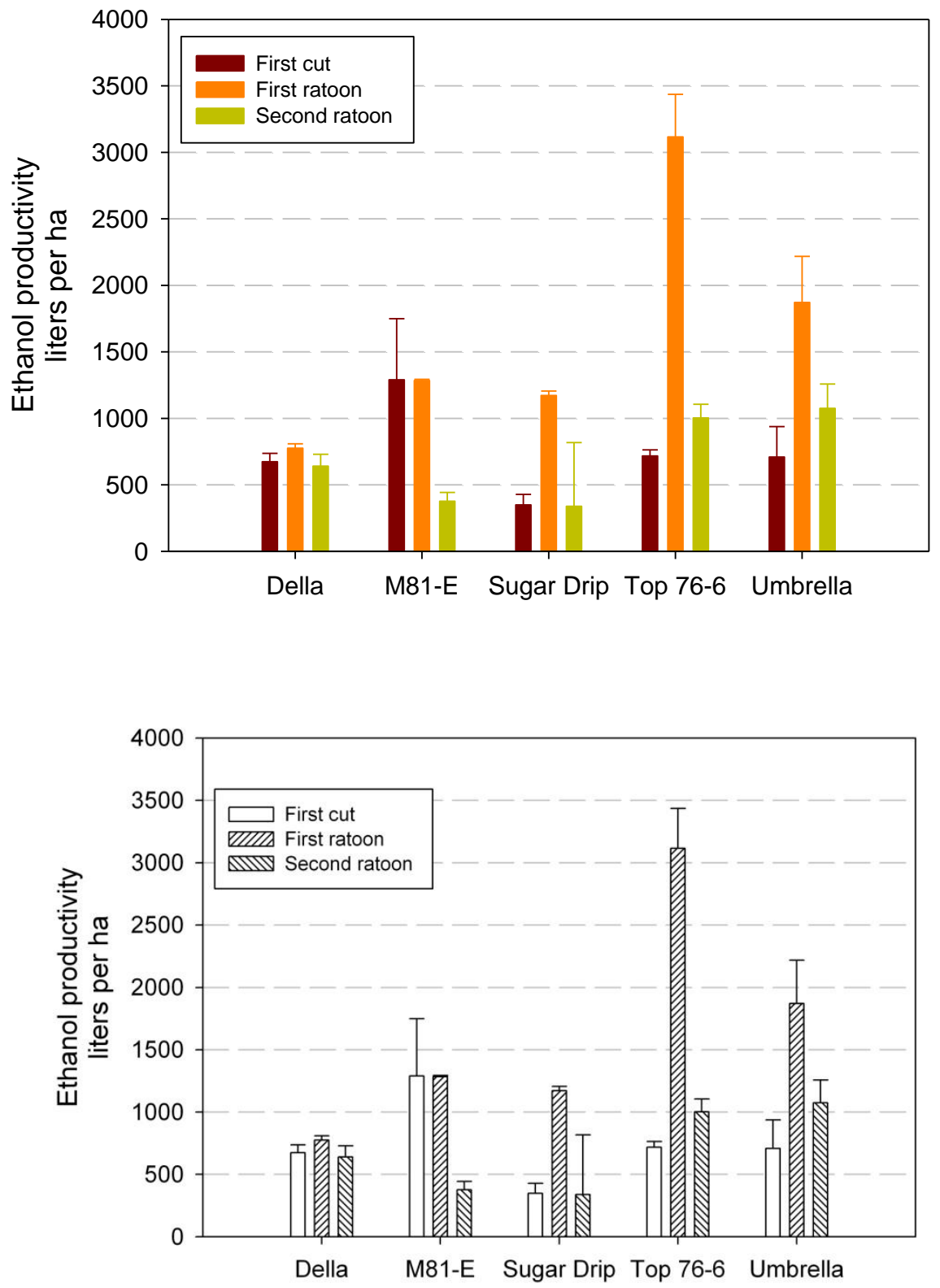
- Three harvests were

obtained per year for five sweet sorghum varieties:

$\square \quad$ First cut

$\square$ First ratoon

$\square$ Second ratoon

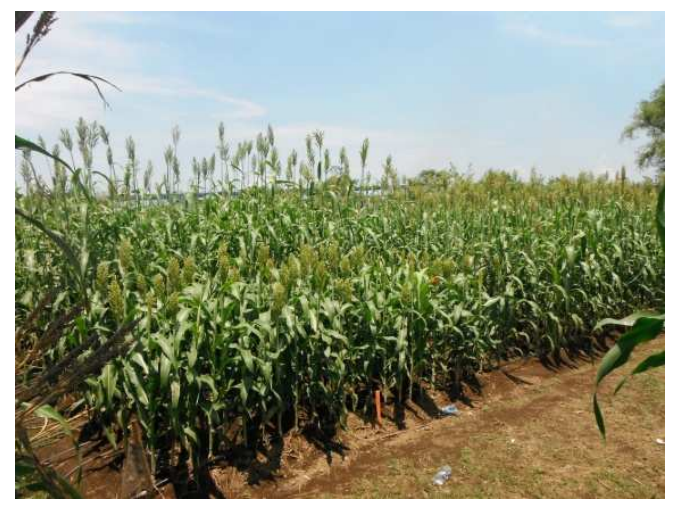

Simultaneous

sugar

extraction

\& fermentation to ethanol of

sweet sorghum

stalk particles

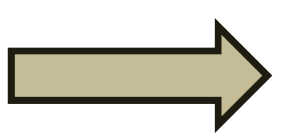

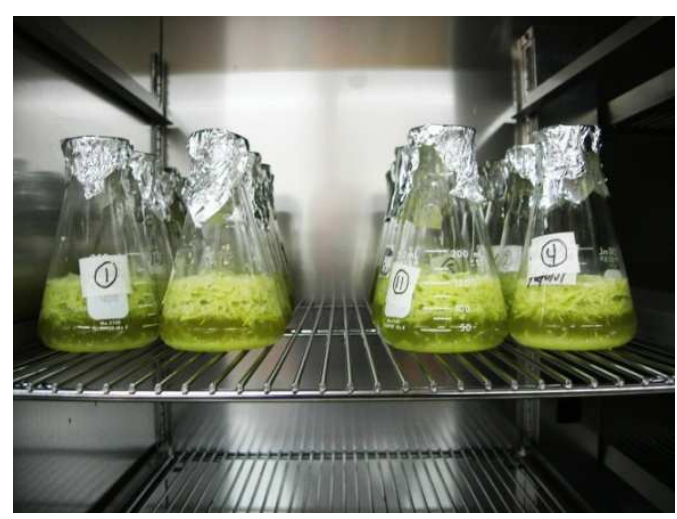

$\square \quad$ The Top 76-6 variety gave the highest fresh stalk biomass, sugar and ethanol productivities 